\title{
SANÇÕES JURÍDICAS NA ESTRUTURA DE INCENTIVOS DOS AGENTES ECONÔMICOS EM PROL DA TUTELA AMBIENTAL TRABALHISTA
}

\author{
LEGAL SANCTIONS IN THE INCENTIVE STRUCTURE OF ECONOMIC AGENTS \\ FOR PROTECTION OF THE WORKING ENVIRONMENT
}

\section{SANCIONES JURÍDICAS EN LA ESTRUCTURA DE INCENTIVOS DE LOS AGENTES ECONÓMICOS EN PROL DE LA TUTELA AMBIENTAL DEL TRABAJO}

BenJAMIn MiRAnda TABAK

http://orcid.org/0000-0002-7935-3188 / http://lattes.cnpq.br/7238063563586831 / benjaminm.tabak@gmail.com

Doutor pela Universidade de Brasília. Professor da Fundação Getúlio Vargas, Escola de Políticas Públicas e Governo, Brasília, DF. Pesquisador $1 C$ do CNPq. Brasília, DF, Brasil.

ANDRÉ VINICIUS MELATTI

http://orcid.org/0000-0001-5270-3099 /http://lattes.cnpq.br/2524789739188164 / andremelatti@hotmail.com

Procurador do Trabalho no Ministério Público do Trabalho (PRT da 09ª Região), mestrando em Direito na Universidade Católica de Brasília (UCB). Umuarama, PR, Brasil.

\begin{abstract}
RESUMO
O artigo propõe analisar as principais sanções jurídicas a que estão sujeitos os agentes econômicos que degradam o meio ambiente do trabalho e como elas influenciam a estrutura de incentivos na adoção de condutas que tenham como finalidade proteger a vida, saúde e segurança dos trabalhadores. Aborda os institutos de responsabilidade civil que incidem na área ambiental trabalhista, destacando a jurisprudência de Tribunais Superiores sobre a matéria e, com amparo em instrumentais fornecidos pela Análise Econômica do Direito, analisa a eficiência de multas cominatórias fixadas em Termos de Ajuste de Conduta firmados com o Ministério Público do Trabalho. Desenvolve a hipótese de necessidade de sustentabilidade dos empreendimentos econômicos, de maneira a evitar externalidades negativas que afetem a dimensão socioambiental da dignidade humana do trabalhador e custos com pagamento de indenizações e multas cominatórias decorrentes de dano ao meio ambiente laboral.
\end{abstract}

Palavras-chave: Direitos Humanos Ambientais; Meio Ambiente do Trabalho; Responsabilidade Civil Ambiental.

\section{ABSTRACT}

The article proposes to analyze the key legal sanctions to which economic agents that degrade the working environment are subjected and how said sanctions influence the incentive structure in the adoption of behaviors that aim to protect the life, health and safety of workers. The paper further covers civil liability institutes that focus on labor areas, highlighting Supreme Court decisions over the matter and analyzes the efficiency of coercive fines fixed in the Conduct Adjustment Agreement signed by the Ministry of Labor, focusing on instruments provided by the economic analysis of law. The article develops the hypothesis of the need for economic enterprise sustainability in order to prevent negative externalities that affect the social and environmental dimensions of the worker's human dignity and also costs with reparation payments and coercive fines arising from damages in the working environment.

Keywords: Working Human Rights; Working Environment; Environmental Liability. 


\section{RESUMEN}

El artículo propone analizar las principales sanciones jurídicas a que están sujetos los agentes económicos que degradan el medio ambiente del trabajo y cómo influyen en la estructura de incentivos en la adopción de conductas que tengan como finalidad proteger la vida, salud y seguridad de los trabajadores. Aborda los institutos de responsabilidad civil que inciden en el área ambiental laboral, destacando la jurisprudencia de Tribunales Superiores sobre la materia y, con amparo en instrumentos proporcionados por el Análisis Económico del Derecho, analiza la eficiencia de multas cominatorias fijadas en Términos de Ajuste de Conducta firmados con el Ministerio Público del Trabajo. Se desarrolla la hipótesis de necesidad de sostenibilidad de los emprendimientos económicos, de manera a evitar externalidades negativas que afecten la dimensión socioambiental de la dignidad humana del trabajador y costos con pago de indemnizaciones y multas cominatorias derivadas de daño al medio ambiente laboral.

Palabras clave: Derechos Humanos Ambientales; Medio Ambiente del Trabajo; Responsabilidad Civil Ambiental.

\section{SUMÁRIO}

INTRODUÇAO; 1 SANÇÕES JURÍDICAS NA ESTRUTURA DE INCENTIVOS DOS AGENTES EMPRESARIAIS; 2 RESPONSABILIDADE CIVIL AMBIENTAL NAS RELAÇÕES DE TRABALHO; 2.1 Responsabilidade civil por dano material coletivo; 2.2 Responsabilidade civil por dano moral coletivo; 3 EFICIÊNCIA DAS MULTAS COMINATÓRIAS FIXADAS EM TERMOS DE AJUSTE DE CONDUTA PELO MINISTÉRIO PÚBLICO DO TRABALHO; CONCLUSÃO; REFERÊNCIAS.

\section{INTRODUÇÃO}

Considerando que a Análise Econômica do Direito permite inferir o grau de influência de normas jurídicas no comportamento de determinados agentes e organizações ${ }^{1}$, o presente artigo busca analisar as principais sanções jurídicas a que estão sujeitos os agentes econômicos que degradam o meio ambiente do trabalho, à luz de contornos modernos da responsabilidade civil ambiental. Além disso, pretende verificar como elas influenciam a estrutura de incentivos dos agentes econômicos na adoção de condutas que tenham como finalidade proteger a vida, a saúde e a segurança dos trabalhadores, evitando-se a degradação ambiental com repercussão nas relações de trabalho.

No Capítulo 1, é desenvolvido o potencial que as normas jurídicas acarretam na estrutura de incentivos dos agentes econômicos, de modo a alterar os elementos que integram a tomada de decisão na tutela do meio ambiente laboral, evitando-se a geração de externalidades negativas para a sociedade e os trabalhadores coletivamente considerados. Destaca-se os princípios que regem a atividade econômica, com amparo na Constituição da República

1 NÓBREGA, Antonio Carlos Vasconcellos. A Nova Lei de Responsabilização de Pessoas Jurídicas como Estrutura de Incentivos aos Agentes. Economic Analysis of Law Review, Brasília, v. 5, n. 1, jan./jun. 2014. p. 64. 
ISSN 1981-3694

(DOI): $10.5902 / 1981369427743$

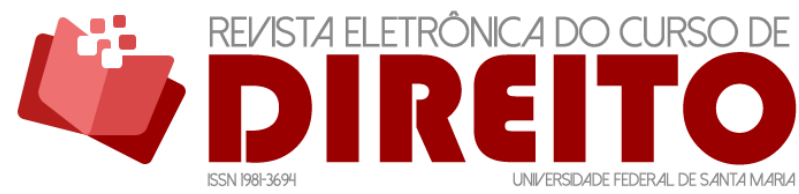

SANÇÕES JURÍDICAS NA ESTRUTURA DE INCENTIVOS DOS AGENTES ECONÔMICOS EM PROL DA TUTELA AMBIENTAL

TRABALHISTA

BENJAMIN MIRANDA TABAK ANDRÉ VINICIUS MELATTI

Federativa do Brasil, bem como a necessidade de sustentabilidade do empreendimento econômico, em sua tríplice dimensão: econômica, social e ambiental.

No Capítulo 2, é abordado o instituto da responsabilidade civil que incide na área ambiental trabalhista, na condição de reação do sistema jurídico para a ação ou omissão que estiver em desconformidade com as suas regras e princípios. São analisadas as funções reparatória e preventiva da responsabilidade civil ambiental, à luz de seus contornos atuais em busca da tutela integral da vida, saúde e integridade física do homem trabalhador. Desenvolve a aplicação da responsabilidade civil objetiva na hipótese de lesão ambiental trabalhista, bem como a divisão da indenização em duas espécies: por dano material coletivo e por dano moral coletivo. Em ambos os casos são trazidas pesquisas jurisprudenciais de Tribunais Superiores.

No Capítulo 3, por fim, utilizam-se instrumentais da teoria econômica para analisar a eficiência de multas cominatórias pecuniárias fixadas em Termos de Ajuste de Conduta firmados com o Ministério Público do Trabalho, de maneira a evitar externalidades negativas que afetem a dimensão socioambiental da dignidade humana do trabalhador e custos com pagamento de indenizações e multas cominatórias decorrentes de dano ao meio ambiente laboral. Partindo-se do pressuposto de que o responsável pelo ato ilícito deve, inexistindo excludentes de responsabilização, indenizar a parte que suportou prejuízos ou interromper as interferências indevidas" $^{2}$, é feita uma pesquisa de dados no sistema "MPT Delphos" para verificar a reincidência de condutas que possam degradar o meio ambiente laboral.

Os métodos científicos utilizados são a dogmática, por intermédio de estratégias de argumentação baseadas em normas jurídicas nacionais e internacionais em vigor no ordenamento brasileiro, e a consulta bibliográfica, desenvolvida com fundamento em doutrina divulgada em revistas especializadas e livros técnicos. Utiliza-se também, especialmente no Capítulo 3, de pesquisa empírica, através de dados de investigações conduzidas atualmente pelo Ministério Público do Trabalho, extraídas do sistema integrado nacional denominado "MPT Delphos", a fim de possibilitar a confirmação da hipótese desenvolvida no presente estudo.

2 PORTO, Antônio José Maristrello; FRANCO, Paulo Fernando. Uma Análise Também Econômica do Direito de Propriedade. Economic Analysis of Law Review, Brasília, v. 7, n. 1, jan./jun. 2016. p. 217. 


\section{SANÇÕES JURÍDICAS NA ESTRUTURA DE INCENTIVOS DOS AGENTES}

\section{EMPRESARIAIS}

Os agentes econômicos, ao organizarem suas atividades empresariais, respondem a certos incentivos e, por meio de um comportamento racional, buscam maximizar os ganhos e minimizar as perdas ${ }^{3}$. O estudo das sanções jurídicas decorrentes de condutas que afetam negativamente o meio ambiente do trabalho, por meio da análise das diversas modalidades de indenizações resultantes da responsabilidade civil, tem a aptidão de influenciar diretamente o comportamento dos agentes infratores, no momento destes avaliarem eventuais ganhos e perdas gerados pela adoção de conduta que interfira na vida, saúde e segurança dos trabalhadores.

À luz da teoria econômica, conforme exposto por Benjamin Miranda Tabak, torna-se possível antever, em algum grau, o potencial efeito que a introdução de normas jurídicas acarreta na estrutura de incentivos a que os agentes estão expostos, levando a alterações na tomada de decisão, quando da avaliação de custos e benefícios privados, de maneira a evitar externalidades que sejam negativas para a sociedade ${ }^{4}$. Nesse aspecto, a Análise Econômica do Direito é um instrumental valioso no exame da eficiência das sanções jurídicas decorrentes do instituto da responsabilidade civil ambiental nas relações de trabalho.

A ordem econômica, fundada na valorização do trabalho humano e na livre iniciativa, deve assegurar a todos uma existência digna, nos termos do artigo 170 da Constituição da República ${ }^{5}$, valendo ressaltar que a economia precisa de um conjunto mínimo de regras para o seu bom funcionamento, sem o qual não seria possível construir um sistema eficiente ${ }^{6}$. Não obstante a economia de livre mercado possibilite a alocação de recursos com base em decisões pessoais, verifica-se que a tutela do meio ambiente é um dever do agente empresarial, sem a qual viola-se o direito fundamental socioambiental dos seus trabalhadores.

\footnotetext{
${ }^{3}$ NÓBREGA, Antonio Carlos Vasconcellos. A Nova Lei de Responsabilização de Pessoas Jurídicas como Estrutura de Incentivos aos Agentes. Economic Analysis of Law Review, Brasília, v. 5, n. 1, jan./jun. 2014. p. 64.

${ }^{4}$ TABAK, Benjamin Miranda. Análise Econômica do Direito: Proposições Legislativas e Políticas Públicas. Revista de Informação Legislativa, Brasília, ano 52, n. 205, jan./fev. 2015. p. 6.

5 "Art. 170. A ordem econômica, fundada na valorização do trabalho humano e na livre iniciativa, tem por fim assegurar a todos existência digna, conforme os ditames da justiça social [...]." BRASIL. Constituição Federal. Diário Oficial da República Federativa do Brasil, Brasília, 5 out. 1988. Disponível em: http://www.planalto.gov.br/ccivil_03/constituicao/constituicao.htm. Acesso em 2 abr. 2018.

${ }^{6}$ UCHÔA, Carlos Frederico Azeredo. A Acepção do Pleno Emprego no Texto Constitucional de 1998. Economic Analysis of Law Review, Brasília, v. 7, n. 2, jul./dez. 2016. p. 626.
} 
A análise do comportamento dos agentes empresariais, em face das dimensões social e ambiental da dignidade dos trabalhadores envolvidos com a respectiva atividade econômica, decorre do fato de que entre os custos e benefícios das decisões está a reação dos indivíduos que se relacionam com o tomador de decisões e que podem ser afetados em função das escolhas realizadas $^{7}$. Em decorrência do vínculo jurídico existente entre as partes que integram a relação de trabalho, constata-se que o resguardo da vida, saúde e integridade física dos trabalhadores deve integrar a organização e gestão dos empreendimentos econômicos. Afinal, o agente econômico preocupado em ser cumpridor de normas jurídicas ambientais deve considerar a internalização de externalidades negativas ocasionadas por sua atividade ${ }^{8}$.

Com efeito, o comportamento dos agentes econômicos, em relação à busca de soluções para a proteção do meio ambiente, deve se pautar sob a perspectiva da sustentabilidade ${ }^{9}$, através de uma melhor integração dos aspectos econômicos, sociais e ambientais. Esses três pilares interdependentes do desenvolvimento sustentável constam da Declaração de Joanesburgo sobre Desenvolvimento Sustentável, aprovado durante a Cúpula Mundial sobre Desenvolvimento Sustentável ("RIO+10") realizada em setembro de 2002 na África do Sul, no âmbito da Organização das Nações Unidas $(\mathrm{ONU})^{10}$, como se observa no seguinte trecho: "Assumimos a responsabilidade coletiva de fazer avançar e fortalecer os pilares interdependentes e que se sustentam mutuamente do desenvolvimento sustentável - desenvolvimento econômico, desenvolvimento social e proteção ambiental - nos âmbitos local, nacional, regional e global”.

O Supremo Tribunal Federal já reconheceu que o princípio do desenvolvimento sustentável encontra assento constitucional, extraindo-se do seu conteúdo normativo que a incolumidade do meio ambiente não pode ser comprometida por interesses empresariais nem ficar dependente de motivações de índole meramente econômica ${ }^{11}$. A maximização dos ganhos e

\footnotetext{
7 SILVA, Ênio Alexandre Gomes Bezerra da; AGUIAR, Julio Cesar de; TABAK. Benjamin Miranda. Incentivos Fiscais Capturados pelos Oligopólios: Uma Perspectiva da Análise Econômica do Direito. In: TABAK, Benjamin Miranda; AGUIAR, Julio Cesar de (Org.). Análise Econômica do Direito: Uma Abordagem Aplicada. Porto Alegre: Núbia Fabris, 2015. p. 83.

8 FORNASIER, Mateus de Oliveira. Princípio da Precaução e Regulação do Risco Nanotecnológico: Consequências Econômicas. Economic Analysis of Law Review, Brasília, v. 5, n. 2, jul./dez. 2014. p. 309.

9 SAMPAIO, Dayana Almeida Fraga; TABAK, Benjamin Miranda; AGUIAR, Julio Cesar de. A Outorga do Uso da Água à Luz dos Direitos de Propriedade. TABAK, Benjamin Miranda; AGUIAR, Julio Cesar de (Org.). Análise Econômica do Direito: Uma Abordagem Aplicada. Porto Alegre: Núbia Fabris, 2015. p. 97.

10 OLIVEIRA, Liziane Paixão Silva; MONT'ALVERNE, Tarin Cristino Frota. A Evolução da Noção de Desenvolvimento Sustentável na Conferência das Nações Unidas. REI, Fernando; GRANZIERA, Maria Luiza Machado (Org.). Direito Ambiental Internacional: Avanços e Retrocessos. São Paulo: Atlas, 2015. p. 125. 11 “(...) A ATIVIDADE ECONÔMICA NÃO PODE SER EXERCIDA EM DESARMONIA COM OS PRINCÍPIOS DESTINADOS A TORNAR EFETIVA A PROTEÇÃO AO MEIO AMBIENTE. - A incolumidade do meio ambiente não
} 
a minimização das perdas, com base em condutas empresariais pautadas em uma estrutura de custos e benefícios existentes, deve necessariamente considerar as normas jurídicas que regem a responsabilidade civil, as quais possuem a capacidade de inibir a conduta dos infratores.

Os agentes econômicos, portanto, devem organizar os seus empreendimentos de maneira a buscar o desenvolvimento equilibrado e saudável da vida humana no ambiente de trabalho, por meio do cumprimento de normas de saúde e segurança do trabalho. Isso porque, na hipótese das atividades empresariais resultarem em externalidades negativas, gerando um impacto deletério da conduta de determinado agente sobre o bem-estar de terceiros ${ }^{12}$, especialmente dos trabalhadores que estão envolvidos diretamente no processo produtivo, incidirão as normas de responsabilidade civil relacionadas ao ilícito ambiental trabalhista.

\section{RESPONSABILIDADE CIVIL AMBIENTAL NAS RELAÇÕES DE TRABALHO}

O ordenamento jurídico brasileiro, a partir da promulgação da Constituição de 1988, deu novo tratamento jurídico à responsabilidade civil, voltando-se com primazia para o resguardo da pessoa humana, nos planos individual e coletivo (artigo $1^{\circ}$, III, da CRFB), em face de ofensa ou ameaça aos direitos fundamentais que the foram outorgados ${ }^{13}$. Nesse sentido, a responsabilidade civil desponta como sendo a reação do sistema jurídico para a ação ou omissão que estiver em desconformidade com as suas regras e princípios, evitando-se a repercussão negativa da conduta ilícita na coletividade.

Enquanto instituto jurídico, a responsabilidade civil é a obrigação de reparar um prejuízo causado a outrem, referindo-se inevitavelmente ao dever de indenizar. Conforme doutrina do eminente jurista José Affonso Dallegrave Neto, o instituto da responsabilidade civil

pode ser comprometida por interesses empresariais nem ficar dependente de motivações de índole meramente econômica, ainda mais se se tiver presente que a atividade econômica, considerada a disciplina constitucional que a rege, está subordinada, dentre outros princípios gerais, àquele que privilegia a 'defesa do meio ambiente' (CF, art. 170, VI), que traduz conceito amplo e abrangente das noções de meio ambiente natural, de meio ambiente cultural, de meio ambiente artificial (espaço urbano) e de meio ambiente laboral." BRASIL. Supremo Tribunal Federal. Ação Direta de Inconstitucionalidade (ADIn) n. ${ }^{\circ}$ 3540-1 MC/DF. Procurador-geral da República e Presidente da República. Relator: Ministro Celso de Mello. 1 set. 2005. Disponível em: http: / /redir.stf.jus.br/paginadorpub/paginador.jsp?docTP=AC\&docID=387260. Acesso em: 2 abr. 2018.

12 PORTO, Antônio José Maristrello; GOMES, Lucas Thevenard. Análise Econômica da Função Social dos Contratos: Críticas e Aprofundamentos. Economic Analysis of Law Review, Brasília, v. 1, n. 2, jul./dez. 2010. p. 204.

${ }_{13}$ MEDEIROS NETO, Xisto Tiago de. A Responsabilidade Civil Objetiva: da Teoria da Culpa à Teoria do Risco. Revista do Ministério Público do Trabalho no Rio Grande do Norte, Natal, PRT da $21^{\text {a }}$ Região, set. 2015. p. 24. 
ISSN 1981-3694

(DOI): $10.5902 / 1981369427743$

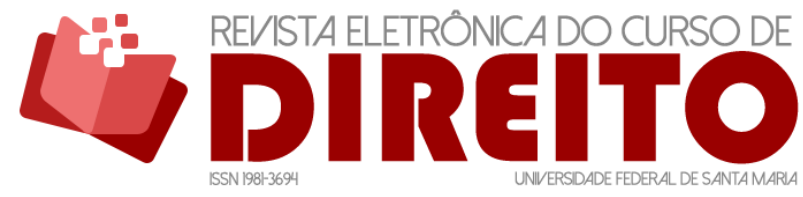

SANÇÕES JURÍDICAS NA ESTRUTURA DE INCENTIVOS DOS AGENTES ECONÔMICOS EM PROL DA TUTELA AMBIENTAL TRABALHISTA

BenJAMIN MiRANDA TABAK ANDRÉ VINICIUS MELATTI

pode ser concebido como a sistematização de normas jurídicas que objetivam a reparação do dano patrimonial e a compensação do dano extrapatrimonial causados diretamente por agente ou por fato de coisas ou pessoas que dele dependam - que agiu de forma ilícita ou assumiu o risco da atividade causadora da lesão ${ }^{14}$.

Ao lado da função eminentemente reparatória, a responsabilidade civil passa a se ocupar na atualidade da potencialidade do dano ambiental, antes mesmo de sua concretização. A tutela preventiva dos danos ambientais passa a ter prioridade à sua reparação, não obstante os efeitos da condenação do agente poluidor estimularem atitudes por parte dos envolvidos em situações semelhantes, no sentido de adotar certas medidas para evitar que outros danos ambientais sejam causados ${ }^{15}$. Houve uma ampliação das funções da responsabilidade civil, tornando desnecessária a efetiva concretização do dano ambiental, bastando a mera exposição de interesses juridicamente relevantes aos seus riscos.

A principal finalidade de um sistema de responsabilidade civil consiste em gerar incentivos capazes de evitar situações danosas, ou seja, internalizar as externalidades negativas a fim de conduzir a decisões ótimas acerca do nível de precaução ${ }^{16}$. Para tanto, exige-se do agente econômico, na tutela do meio ambiente do trabalho, o emprego antecipado de medidas certas que possam evitar a ocorrência de um dano provável em determinada situação, eliminando ou reduzindo suas causas, quando tiver conhecimento de um risco concreto, bem como a adoção antecipada de medidas acautelatórias amplas que possam evitar a ocorrência de possível ameaça à saúde e segurança do trabalhador, considerando o risco abstrato e potencial ${ }^{17}$.

0 atual Código Civil brasileiro (Lei n. ${ }^{0}$ 10.406/2002) dispõe em seu artigo 927 que aquele que, por ato ilícito, causar dano a outrem, fica obrigado a repará-lo. Já o inciso III do artigo 932, cumulado com o artigo 933 do mesmo diploma legal, estabelece que o empregador ou comitente, ainda que não haja culpa de sua parte, também são responsáveis pela reparação civil pelos atos praticados por seus empregados e prepostos, no exercício do trabalho que thes

\footnotetext{
${ }^{14}$ DALLEGRAVE NETO, José Affonso. Responsabilidade Civil no Direito do Trabalho. São Paulo: LTr, 2010. p. 99-100.

15 LEITE, José Rubens Morato; AYALA, Patryck de Araújo. Dano Ambiental: do Individual ao Coletivo Extrapatrimonial: Teoria e Prática. São Paulo: Revista dos Tribunais, 2015. p. 148-149.

${ }^{16}$ SAMPAIO, Dayana Almeida Fraga; TABAK, Benjamin Miranda; AGUIAR, Julio Cesar de. A Responsabilidade Civil sob a Ótica da Teoria dos Jogos. In: TABAK, Benjamin Miranda; AGUIAR, Julio Cesar de (Org.). Análise Econômica do Direito: Uma Abordagem Aplicada. Porto Alegre: Núbia Fabris, 2015. p. 178.

17 GEMIGNANI, Tereza Aparecida Asta; GEMIGNANI, Daniel. Meio Ambiente do Trabalho: Precaução e Prevenção: Princípios Norteadores de Um Novo Padrão Normativo. In: Revista do Ministério Público do Trabalho, n. 43. Brasília: LTr, mar. 2012. p. 57-58.
} 
competir ou em razão dele. A parte final do artigo 942 preceitua que, se a ofensa ou violação do direito tiver mais de um autor, todos responderão solidariamente pela reparação.

À luz desses dispositivos legais, constata-se inicialmente que a responsabilidade civil pode ser direta, quando o próprio causador do dano praticou o fato, ou indireta, quando o terceiro que comete o ato lesivo a outrem é, de alguma forma, ligado ao responsável pela reparação civil. Desse modo, percebe-se desde logo que a prática pessoal do dano não é elemento essencial para a configuração da responsabilidade civil ambiental, a qual também incide em decorrência de atos de terceiros, especialmente quando existe vínculo jurídico entre o responsável e o agente que praticou o dano ou sua ameaça.

O Código Civil de 2002 também consagrou, como norma jurídica de caráter geral, as duas vertentes da responsabilidade civil, quais sejam, a subjetiva e a objetiva. Para a configuração da responsabilidade civil subjetiva, é necessário o preenchimento dos seguintes elementos: a) conduta dolosa ou culposa contrária à norma jurídica; b) dano; e c) nexo de causalidade entre a conduta e o dano. Exige-se que, no momento da conduta, o sujeito tenha tido a intenção de causar prejuízo (dolo) ou o tenha causado por agir com menos cuidado que o esperado (culpa) $)^{18}$. É o que está disposto nos artigos 186 e 927:

Art. 186. Aquele que, por ação ou omissão voluntária, negligência ou imprudência, violar direito e causar dano a outrem, ainda que exclusivamente moral, comete ato ilícito.

Art. 927. Aquele que, por ato ilícito (arts. 186 e 187), causar dano a outrem, fica obrigado a repará-lo. ${ }^{19}$

Já na responsabilidade civil objetiva, os elementos para a sua configuração são: a) o exercício de certa atividade; b) o dano; e c) o nexo de causalidade entre o dano e a atividade. Esta modalidade volta-se precipuamente para a reparação do evento danoso, não se exigindo a valoração da conduta dolosa ou culposa do agente. A sua previsão no Código Civil está no parágrafo único do artigo 927:

Parágrafo único. Haverá obrigação de reparar o dano, independentemente de culpa, nos casos especificados em lei, ou quando a atividade normalmente

18 TEPEDINO, Gustavo; BARBOZA, Heloisa Helena; MORAES, Maria Celina Bodin de. Código Civil Interpretado Conforme a Constituição da República. Rio de Janeiro: Renovar, 2006. v. I. p. 337.

19 BRASIL. Lei $\mathrm{n}^{\circ}$ 10.406, de 10 de janeiro de 2002. Institui o Código Civil. Diário Oficial da República Federativa do Brasil, Brasília, 11 jan. 2002. Disponível em: http://www.planalto.gov.br/ccivil_03/leis/2002//10406.htm. Acesso em: 2 abr. 2018. 
ISSN 1981-3694

(DOI): $10.5902 / 1981369427743$

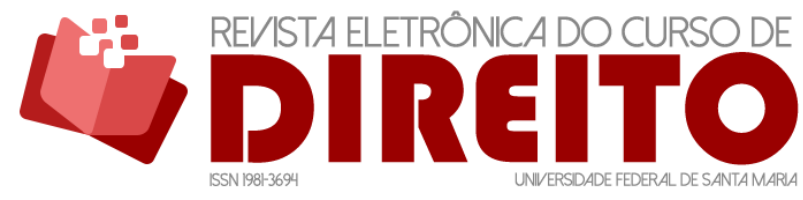

SANÇÕES JURÍDICAS NA ESTRUTURA DE INCENTIVOS DOS AGENTES ECONÔMICOS EM PROL DA TUTELA AMBIENTAL

TRABALHISTA

BENJAMIN MIRANDA TABAK ANDRÉ VINICIUS MELATTI

desenvolvida pelo autor do dano implicar, por sua natureza, risco para os direitos de outrem. ${ }^{20}$

A responsabilidade civil objetiva pode decorrer, portanto, tanto de previsão legal quanto do exercício de atividade de risco, sendo que ambas desconsideram a noção de culpabilidade do agente ou responsável. Logo, ainda que inexista norma jurídica estabelecendo a responsabilidade objetiva, haverá o dever de reparação ou indenização do dano quando os serviços ou a atividade desenvolvida pelo agente, pelas suas próprias características e natureza, apresentam risco de causar danos à esfera de interesse alheios ${ }^{21}$, uma vez que o sujeito privilegiado pelas vantagens ou benefícios do negócio deve responder por riscos inerentes à sua atividade econômica, mesmo que envide todos os esforços no sentido de evitar o dano 22 .

Verifica-se que a complexidade das relações sociais e econômicas fez surgir um sistema de responsabilização com base na teoria do risco, segundo a qual quem exerce determinadas atividades deve ser responsável pelos seus riscos, independentemente de quaisquer considerações em torno do seu comportamento pessoal. Essa espécie de responsabilidade civil denomina-se objetiva, devendo apresentar os seguintes requisitos para a sua configuração: a) o exercício de certa atividade; b) o dano; e c) o nexo de causalidade entre o dano e a atividade ${ }^{23}$.

Isso porque o $\$ 3^{\circ}$ do artigo 225 da Constituição da República, ao estabelecer a “obrigação de reparar os danos causados" ao meio ambiente, não traz qualquer elemento subjetivo para a configuração da responsabilidade civil, bastando, assim, a existência do dano ou sua ameaça e o nexo causal com a conduta comissiva ou omissiva ilícita. No mesmo sentido é o $\S 1^{\circ}$ do artigo 14 da Lei $n .^{\circ}$ 6.938/1981, ao estipular que o agressor fica obrigado, independentemente da existência de culpa, a indenizar ou reparar os danos causados ao meio ambiente e a terceiros, afetados por sua atividade.

Tendo em vista que o dano é pressuposto necessário da obrigação de reparar e, por consequência, elemento essencial para estabelecer a responsabilidade civil, é necessário registrar que o dano na área ambiental pode designar tanto as alterações nocivas ao conjunto do

20 BRASIL. Lei $n^{\circ} 10.406$, de 10 de janeiro de 2002. Institui o Código Civil. Diário Oficial da República Federativa do Brasil, Brasília, 11 jan. 2002. Disponível em: http://www.planalto.gov.br/ccivil_03/leis/2002//10406.htm. Acesso em: 2 abr. 2018.

21 MEDEIROS NETO, Xisto Tiago de. A Responsabilidade Civil Objetiva: da Teoria da Culpa à Teoria do Risco. Revista do Ministério Público do Trabalho no Rio Grande do Norte, Natal, PRT da $21^{\text {a }}$ Região, set. 2015. p. 26.

${ }^{22}$ SANTOS, Enoque Ribeiro dos. Responsabilidade Objetiva e Subjetiva do Empregador em Face do Novo Código Civil. São Paulo: LTr, 2008. p. 20.

23 TEPEDINO, Gustavo; BARBOZA, Heloisa Helena; MORAES, Maria Celina Bodin de. Código Civil Interpretado Conforme a Constituição da República. Rio de Janeiro: Renovar, 2006. v. II. p. 805. 
meio ambiente quanto os efeitos que tal alteração provoca na saúde das pessoas e em seus interesses ${ }^{24}$. Esse é o conceito adotado no ordenamento jurídico brasileiro, ao dispor no $\$ 1^{\circ}$ do artigo 14 da Lei n. ${ }^{\circ}$ 6.938/1981 que o poluidor é obrigado a reparar os danos causados ao meio ambiente e a terceiros ${ }^{25}$, dando ensejo ao reconhecimento da responsabilidade civil em duas modalidades: por dano material coletivo e por dano moral coletivo.

\subsection{Responsabilidade civil por dano material coletivo}

A prioridade da responsabilidade civil na área ambiental é a prevenção de danos, e não o seu ressarcimento ou reparação. Entretanto, há inúmeras situações de fato em que a lesão do meio ambiente não é evitada pela conduta adotada pelo agente, ocasionando uma ruptura do equilíbrio ambiental, em seus mais variados aspectos: natural, cultural, artificial e do trabalho. Desse modo, pode-se definir o dano material ambiental nas relações de trabalho como sendo as manifestações degradadoras perpetradas pelo agente econômico ou decorrentes de atividades de risco exercidas por este perante o patrimônio ambiental, capazes de romper com o equilíbrio garantido por normas jurídicas de saúde e segurança do trabalho ${ }^{26}$.

O dano material ambiental é aquele que provoca degradação ambiental, ou seja, acarreta a modificação adversa das características do meio ambiente, afetando o seu necessário equilíbrio. $O$ inciso III do artigo $3^{\circ}$ da Lei $n .^{\circ}$ 6.938/1981 traz um rol exemplificativo das atividades degradantes, assim consideradas aquelas que direta ou indiretamente:
a) prejudiquem a saúde, a segurança e o bem-estar da população;
b) criem condições adversas às atividades sociais e econômicas;
c) afetem desfavoravelmente a biota;
d) afetem as condições estéticas ou sanitárias do meio ambiente;

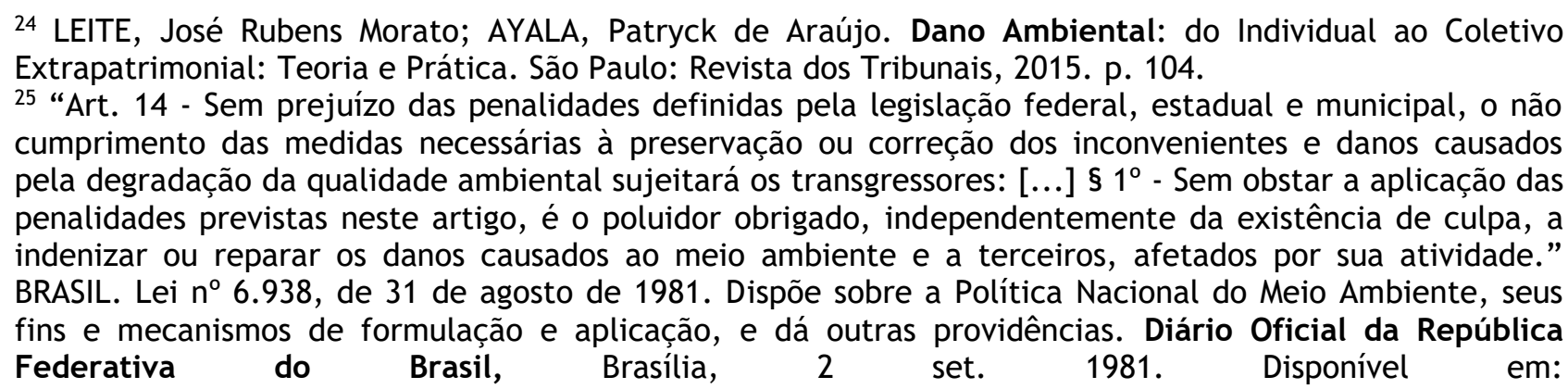
http://www.planalto.gov.br/ccivil_03/leis/L6938.htm. Acesso em: 3 abr. 2018.

26 VIANNA, José Ricardo Alvarez. Responsabilidade Civil por Danos ao Meio Ambiente: À Luz do Novo Código Civil. Curitiba: Juruá, 2004. p. 133. 
e) lancem matérias ou energia em desacordo com os padrões ambientais estabelecidos; ${ }^{27}$

À luz desse conceito normativo, percebe-se que o dano material ambiental pode ser tanto individual quanto coletivo, a depender da esfera de interesses juridicamente atingidos pela lesão ou risco ao meio ambiente. Estar-se-á diante do dano material ambiental coletivo quando este afetar o meio ambiente globalmente considerado, em sua concepção difusa ${ }^{28}$. De outro lado, se a lesão ao meio ambiente se refletir no interesse particular próprio da pessoa, o dano material ambiental será classificado como individual. 0 dano ambiental deve ser compreendido, assim, como toda lesão intolerável causada por qualquer ação humana ao meio ambiente, diretamente, como macrobem de interesse da coletividade, e indiretamente, a terceiros, tendo em vista interesses próprios e individualizáveis que refletem no macrobem ${ }^{29}$.

Uma vez definido o dano material coletivo ambiental, constata-se claramente que a omissão do agente econômico na adoção das providências normativamente determinadas de proteção ao meio ambiente do trabalho, e por consequência da vida, saúde e segurança do trabalhador, configura hipótese de responsabilidade civil ambiental. Importante mencionar, neste ponto, que a própria indiferença para com as normas de proteção ambiental dirigidas ao contexto laboral enseja a responsabilidade civil objetiva, uma vez que a tolerância empresarial com a existência do risco, sem a sua eliminação, ou, quando impossível, sua redução, produz de per si dano ao meio ambiente do trabalho e ao grupo de trabalhadores ${ }^{30}$.

Dispõe o artigo 14 da Lei . $^{\circ}$ 6.938/1981 que o não cumprimento das medidas necessárias à preservação ou correção dos inconvenientes e danos causados pela degradação da qualidade ambiental sujeitará os transgressores às seguintes sanções: a) multa simples ou diária; b) perda ou restrição de incentivos e benefícios fiscais; c) perda ou suspensão de participação em linhas de financiamento em estabelecimentos oficiais de crédito; e d) suspensão de sua

\footnotetext{
27 BRASIL. Lei $n^{\circ}$ 6.938, de 31 de agosto de 1981. Dispõe sobre a Política Nacional do Meio Ambiente, seus fins e mecanismos de formulação e aplicação, e dá outras providências. Diário Oficial da República Federativa do Brasil, Brasília, 2 set. 1981. Disponível em: http://www.planalto.gov.br/ccivil_03/leis/L6938.htm. Acesso em: 3 abr. 2018.

28 DALLEGRAVE NETO, José Affonso. Controvérsias do Dano ao Ambiente de Trabalho. In: FELICIANO, Guilherme Guimarães; URIAS, João; MARANHÃO, Ney (Coord.). Direito Ambiental do Trabalho: Apontamentos para Uma Teoria Geral. São Paulo: LTr, 2017. v. 3. p. 429.

29 LEITE, José Rubens Morato; AYALA, Patryck de Araújo. Dano Ambiental: do Individual ao Coletivo Extrapatrimonial: Teoria e Prática. São Paulo: Revista dos Tribunais, 2015. p. 113-114.

30 BELTRAMELLI NETO, Silvio; LUSTRE, Paola Stolagli. O Direito Fundamental à Saúde e o Acidente de Trabalho: Por Uma Investigação Mais Precisa do Nexo Causal. Revista do Ministério Público do Trabalho, n. 49. Brasília: LTr, mar. 2015. p. 160.
} 
atividade. Além dessas penalidades e de outras previstas na legislação federal, estadual e municipal, o poluidor fica obrigado, independentemente da existência de culpa, a indenizar ou reparar os danos causados ao meio ambiente e a terceiros, afetados por sua atividade ${ }^{31}$.

A reparação e indenização dos danos ambientais é a reação do ordenamento jurídico brasileiro para com a conduta comissiva ou omissiva do agente econômico que afeta o equilíbrio do meio ambiente laboral. Afinal, o empresário tem o dever de adotar todas as cautelas para que o ambiente de trabalho seja um local seguro e saudável, de modo a considerar, na gestão da organização produtiva, todas as hipóteses que possam ser potenciais causadoras de danos ambientais aos trabalhadores ${ }^{32}$. Entretanto, ocorrido o dano ambiental, as sanções jurídicas devem ser dirigidas à reconstituição, à restauração e à substituição do bem degradado.

O próprio Superior Tribunal de Justiça já firmou entendimento no sentido de que “o direito ambiental atua de forma a considerar, em primeiro plano, a prevenção, seguida da recuperação e, por fim, o ressarcimento"33. Em sendo assim, havendo uma falha na sistemática de prevenção de danos ao meio ambiente, o primeiro objetivo a ser almejado é a restituição do patrimônio ambiental ao estado de equilíbrio anterior à prática lesiva. Nem sempre, porém, é possível recompor o bem ambiental lesado, sendo necessário proceder a sua compensação, mediante a substituição por outro funcionalmente equivalente ou por sanção pecuniária.

Em análise dos casos jurisdicionais que envolvem a lesão ambiental com repercussão na sadia qualidade de vida dos trabalhadores, merece destaque a queima da palha da cana de

\footnotetext{
31 “Art 14 - Sem prejuízo das penalidades definidas pela legislação federal, estadual e municipal, o não cumprimento das medidas necessárias à preservação ou correção dos inconvenientes e danos causados pela degradação da qualidade ambiental sujeitará os transgressores: I - à multa simples ou diária, nos valores correspondentes, no mínimo, a 10 (dez) e, no máximo, a 1.000 (mil) Obrigações Reajustáveis do Tesouro Nacional - ORTNs, agravada em casos de reincidência específica, conforme dispuser o regulamento, vedada a sua cobrança pela União se já tiver sido aplicada pelo Estado, Distrito Federal, Territórios ou pelos Municípios; II - à perda ou restrição de incentivos e benefícios fiscais concedidos pelo Poder Público; III - à perda ou suspensão de participação em linhas de financiamento em estabelecimentos oficiais de crédito; IV - à suspensão de sua atividade. $\$ 1^{\circ}$ - Sem obstar a aplicação das penalidades previstas neste artigo, é o poluidor obrigado, independentemente da existência de culpa, a indenizar ou reparar os danos causados ao meio ambiente e a terceiros, afetados por sua atividade." BRASIL. Lei $n^{\circ}$ 6.938, de 31 de agosto de 1981. Dispõe sobre a Política Nacional do Meio Ambiente, seus fins e mecanismos de formulação e aplicação, e dá outras providências. Diário Oficial da República Federativa do Brasil, Brasília, 2 set. 1981. Disponível em: http://www.planalto.gov.br/ccivil_03/leis/L6938.htm. Acesso em: 3 abr. 2018.

32 FERRO, Thania Maria Bastos Lima. A Função Punitiva da Responsabilidade Civil em Acidentes do Trabalho. São Paulo: LTr, 2016. p. 113.

33 BRASIL. Superior Tribunal de Justiça. REsp n. ${ }^{\circ}$ 1115555/MG. Ministério Público do Estado de Minas Gerais e Julio Cesar Vieira Pinto. Relator: Ministro Arnaldo Esteves Lima. 15 fev. 2011. Disponível em: https: / / ww2.stj.jus.br/processo/revista/documento/mediado/?componente=ITA\&sequencial=1036983\&nu m_registro=200900040611\&data=20110223\&formato=PDF. Acesso em: 3 abr. 2018.
} 
açúcar que ainda ocorre em algumas regiões do setor sucroalcooleiro no país. Em julgamento de Ação Civil Pública pelo Superior Tribunal de Justiça, ressaltou-se que a queimada no canavial "libera $\mathrm{CO}_{2}$ recolhido da atmosfera durante 12 a 18 meses em pouco mais de 30 ou 60 minutos" ${ }^{34}$, lançando-se na atmosfera os hidrocarbonetos policíclicos aromáticos (HPAs), componentes altamente cancerígenos, os quais atingem o organismo de cortadores de cana e o ar das imediações, devendo a referida atividade econômica ser desenvolvida com os instrumentos e as tecnologias industriais modernas de redução de impacto ambiental.

Os efeitos degradantes ao meio ambiente do trabalho oriundos de canaviais queimados, com repercussão direta na saúde dos trabalhadores, são indicados em estudo conduzido pela Doutora Katty Maria da Costa Matos, conforme se observa no seguinte trecho:

- os HPAs são substâncias reconhecidas como cancerígenas pelos organismos internacionais de controle e prevenção do câncer;

- a queima da cana de açúcar antes da colheita libera fuligem, que contém HPAs, no ar ambiente e sedimenta-a nos caules da cana a serem posteriormente cortados e no solo. Isto representa, para a população de trabalhadores envolvidos na colheita da cana, risco de intoxicação pelos HPAs tanto por inalação quanto pela via dérmica e significa uma maior probabilidade de incidência de cânceres de pulmão, de bexiga e de pele;

- pelo conhecimento acumulado hoje sobre os mecanismos de carcinogênese, não há limites de tolerância à exposição precisamente definidos para os HPAs, ou seja, níveis abaixo dos quais não haveria risco de iniciação de processo cancerígeno. ${ }^{35}$

Em razão da dificuldade de valoração econômica do patrimônio ambiental lesado na queima da palha da cana de açúcar, cuja degradação atinge diversos aspectos do meio ambiente, o Tribunal de Justiça do Estado de São Paulo vem utilizando como critério objetivo o número de hectares queimados na propriedade, equacionando o poder calorífico e a produtividade admitida. Desse modo, para aferir monetariamente a perda de energia decorrente da queimada, busca-se o equivalente monetário em litros de álcool produzidos, devendo a

\footnotetext{
${ }^{34}$ BRASIL. Superior Tribunal de Justiça. AgRg nos EDcl no REsp 1094873/SP. Agravante: Filipe Salles Oliveira e outro. Agravado: Ministério Público do Estado de São Paulo. Relator: Ministro Humberto Martins. 42 ago. 2009.2 Disponível em: https: / / ww2.stj.jus.br/processo/revista/documento/mediado/?componente=ITA\&sequencial=898714\&nu m_registro=200802154943\&data=20090817\&formato=PDF. Acesso em: 3 abr. 2018.

35 MATTOS, Katty Maria da Costa. Valoração Econômica dos Impactos Causados pela Queima da Cana de Açúcar no Meio Ambiente. 2002. 131 f. Tese (Doutorado em Ciências de Engenharia Ambiental). Escola de Engenharia de São Carlos, São Carlos, 2002. p. 45.
} 
ISSN 1981-3694

(DOI): $10.5902 / 1981369427743$

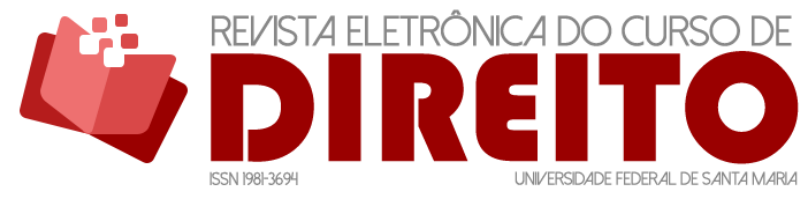

SANÇÕES JURÍDICAS NA ESTRUTURA DE INCENTIVOS DOS AGENTES ECONÔMICOS EM PROL DA TUTELA AMBIENTAL

TRABALHISTA

BENJAMIN MIRANDA TABAK ANDRÉ VINICIUS MELATTI

indenização por dano material coletivo “corresponder ao equivalente ao número de hectares queimados multiplicados pelo preço de 2.048 litros de álcool”36.

Ao lado dos mecanismos de prevenção, recuperação e compensação do dano material ambiental coletivo, o instituto da responsabilidade civil também se direciona, no ordenamento jurídico brasileiro, para a proteção de bens e direitos próprios da coletividade. Nesse aspecto, quando a conduta dos agentes econômicos acarreta consequências nocivas ao equilíbrio do meio ambiente laboral, afetando intoleravelmente valores e interesses fundamentais, de natureza extrapatrimonial, exsurge o dever de indenização do dano moral coletivo.

\subsection{Responsabilidade civil por dano moral coletivo}

O desenvolvimento da vida em um meio ambiente ecologicamente equilibrado, saudável e seguro é um direito fundamental dos trabalhadores, conforme previsão do inciso XXII do artigo $7^{\circ}$ da Constituição da República ${ }^{37}$, reportando-se como valor imaterial da coletividade no ordenamento jurídico brasileiro. Isso porque o dano ambiental promove alterações nocivas nos diversos aspectos do meio ambiente, enquanto direito difuso e coletivo, e também engloba os efeitos que essas alterações geram na vida das pessoas ${ }^{38}$, especialmente trabalhadores que estão em contato direto com o meio ambiente degradado.

Quando a lesão ambiental alcança alguns dos direitos fundamentais de natureza não patrimonial de uma coletividade, ocorre a violação da projeção coletiva da dignidade da pessoa humana, consubstanciada em interesses ou direitos extrapatrimoniais essencialmente coletivos (difusos e coletivos em sentido amplo), "sendo tal violação usualmente causadora de sentimentos coletivos de repulsa, indignação e desapreço pela ordem jurídica"39. Em sede

36 BRASIL. Tribunal de Justiça de São Paulo. Apelação n. ${ }^{\circ}$ 0046930-67.2010.8.26.0506. Apelante: Companhia Albertina Mercantil e Industrial e outros. Apelado: Ministério Público do Estado de São Paulo. Relatora: Desembargadora Vera Angrisani. 19 maio 2016. Disponível em: https: / / esaj.tjsp.jus.br/cjsg/getArquivo.do?conversationld=\&cdAcordao=9453741\&cdForo=0\&uuidCaptcha =sajcaptcha_0ef16528492f447f886e4d384f2f57f4\&vlCaptcha=zxD\&novoVICaptcha. Acesso em: 3 abr. 2018.

37 “Art. $7^{\circ}$. São direitos dos trabalhadores urbanos e rurais, além de outros que visem à melhoria de sua condição social: [...] XXII - redução dos riscos inerentes ao trabalho, por meio de normas de saúde, higiene e segurança”. BRASIL. Constituição Federal. Diário Oficial da República Federativa do Brasil, Brasília, $\quad 5 \quad$ out. $1988 . \quad$ Disponível em: http://www.planalto.gov.br/ccivil_03/constituicao/constituicao.htm. Acesso em 2 abr. 2018.

${ }^{38}$ SILVA, Leticia Rebola Volpi. Compensação Moral Coletiva em Decorrência de llícitos Ambientais. Revista Bonijuris, Curitiba, v. 27, n. 1, jan. 2015. p. 13.

${ }^{39}$ COSTA, Marcelo Freire Sampaio. Dano Moral (Extrapatrimonial) Coletivo. São Paulo: LTr, 2009. p. 71. 
trabalhista, o dano moral coletivo configura-se nos casos de lesão ao meio ambiente do trabalho, decorrente de violação de normas de proteção à saúde e segurança dos trabalhadores.

Com efeito, a lesão a direitos metaindividuais trabalhistas, decorrente de degradação ao meio ambiente laboral, enseja a condenação do agente econômico infrator ao pagamento de indenização por dano moral (extrapatrimonial) causado à coletividade, conforme disposto nos seguintes preceitos da Lei n. ${ }^{\circ}$ 7.347/1985, que regula a Ação Civil Pública:

Art. $1^{\circ}$. Regem-se pelas disposições desta Lei, sem prejuízo da ação popular, as ações de responsabilidade por danos morais e patrimoniais causados:

IV - a qualquer outro interesse difuso ou coletivo.

Art. $3^{\circ}$. A ação civil poderá ter por objeto a condenação em dinheiro ou o cumprimento de obrigação de fazer ou não fazer. ${ }^{40}$

A necessidade de se indenizar a coletividade atingida, mediante a reconstituição, ainda que de forma indireta, dos interesses metaindividuais tutelados pelo ordenamento juslaboral, implica uma condenação em dinheiro do agente econômico poluidor do meio ambiente do trabalho, cujo valor deve levar em conta a natureza do ato ilícito, a gravidade da lesão, o comprometimento do bem jurídico violado e a extensão do dano. Isso porque o descumprimento de direitos mínimos para o resguardo da sadia qualidade de vida e dignidade dos trabalhadores, veiculados em normas que dispõem sobre saúde e segurança laboral, atrai o dever de reparar o dano extrapatrimonial coletivo infligido à sociedade.

A violação intolerável de direitos coletivos (lato sensu) e difusos, com a consequente degradação do meio ambiente do trabalho, exige uma resposta eficaz do sistema jurídico, conforme ensinamentos de Xisto Tiago Medeiros Neto:

O reconhecimento do dano moral coletivo e da imperiosidade da sua adequada reparação traduz a mais importante vertente evolutiva, na atualidade, do sistema de responsabilidade civil, em seus contínuos desdobramentos, a significar a extensão do dano a uma órbita coletiva de direitos, de essência tipicamente extrapatrimonial. São direitos que traduzem valores jurídicos fundamentais da coletividade, que thes são próprios, e que refletem, no horizonte social, o largo alcance da dignidade de seus membros. ${ }^{41}$

40 BRASIL. Lei $n^{\circ} 7.347$, de 24 de julho de 1985. Disciplina a ação civil pública de responsabilidade por danos causados ao meio-ambiente, ao consumidor, a bens e direitos de valor artístico, estético, histórico, turístico e paisagístico (VETADO) e dá outras providências. Diário Oficial da República Federativa do Brasil, Brasília, 25 jul. 2985. Disponível em: http://www.planalto.gov.br/ccivil_03/leis/l7347orig.htm. Acesso em: 3 abr. 2018.

${ }^{41}$ MEDEIROS NETO, Xisto Tiago. Dano Moral Coletivo. São Paulo: LTr, 2012. p. 343. 
As agressões ao meio ambiente do trabalho ferem a valoração que toda a sociedade confere às normas jurídicas que prescrevem condições dignas de trabalho ${ }^{42}$, valendo destacar que a condenação de agentes econômicos por dano à moral difusa tem a aptidão de dissuadir a prática de condutas lesivas à vida, saúde e integridade psicofísica dos trabalhadores, em razão do caráter pedagógico-educativo da referida sanção jurídica. É necessário, portanto, que a fixação da indenização por dano moral coletivo não seja feita em patamares baixos, sob pena de incentivar o agente, quando da análise de custos e benefícios na exploração do seu empreendimento econômico, a decidir pela continuidade da degradação ambiental.

No âmbito da jurisprudência do Tribunal Superior do Trabalho, ao efetuar a consulta unificada em sua página eletrônica de ementas com as expressões "meio ambiente" e "dano moral coletivo", resultam 54 (cinquenta e quatro) ações coletivas envolvendo a tutela do meio ambiente laboral. Já se as referidas expressões forem colacionadas no campo "pesquisa livre", para busca no corpo do texto do acórdão, aparecem 808 (oitocentos e oito) resultados. Em análise dos casos concretos, verifica-se que o entendimento jurisprudencial predominante da Corte é o de que o desrespeito das normas de proteção à saúde, à segurança e ao meio ambiente do trabalho, além de causar prejuízos individuais aos empregados, configura ofensa ao patrimônio moral coletivo, sendo passível de reparação por meio da indenização respectiva ${ }^{43}$.

À luz do exemplo utilizado no tópico anterior acerca da responsabilidade civil por dano material coletivo, observa-se que a poluição provocada pela queimada da palha de cana de açúcar, degradando o meio ambiente natural e do trabalho, "pode causar, paralelamente, um dano ao meio ambiente como interesse difuso, e um dano físico subjetivo nos brônquios e, consequentemente, na capacidade respiratória, danos relativos a interesse individual"44. Entretanto, a lesão a direitos transindividuais se traduz, objetivamente, em ofensa ao patrimônio jurídico da coletividade, que precisa ser recomposto. A caracterização do dano moral

42 CÉSAR, João Batista Martins; MELO, Guilherme Aparecido Bassi de. Condenação por Dano à Moral Difusa como Forma de Prevenir e Punir Agressões ao Meio Ambiente do Trabalho. In: JARDIM, Philippe Gomes; LIRA, Ronaldo José de (Coord.). Meio Ambiente do Trabalho Aplicado: Homenagem aos 10 Anos da CODEMAT. São Paulo: LTr, 2013. p. 127-128.

43 BRASIL. Tribunal Superior do Trabalho. Agravo em Recurso de Revista n. $^{\circ}$ 17066.2013.5.09.0025. Agravante: Construtora Rva Ltda. Agravado: Ministério Público do Trabalho da $9^{\mathrm{a}}$ Região. Relator: Ministro José Roberto Freire Pimenta. 5 abr. 2017. Disponível em: http://aplicacao5.tst.jus.br/consultaunificada2/inteiroTeor.do?action=printInteiroTeor\&format=html\&hig hlight=true\&numeroFormatado=ARR\%20-\%20170-

66.2013.5.09.0025\&base=acordao\&rowid=AAANGhABIAAAM7OAAL\&dataPublicacao=11/04/2017\&local Public acao=DEJT\&query. Acesso em: 3 abr. 2018.

44 LEITE, José Rubens Morato; AYALA, Patryck de Araújo. Dano Ambiental: do Individual ao Coletivo Extrapatrimonial: Teoria e Prática. São Paulo: Revista dos Tribunais, 2015. p. 276. 
coletivo, pois, independe de lesão subjetiva a cada um dos componentes da coletividade, bastando a lesão intolerável à ordem jurídica, e não necessariamente sua repercussão subjetiva ${ }^{45}$.

A condenação do agente econômico à reparação do dano moral causado à coletividade é imprescindível para garantir a tutela dos interesses metaindividuais trabalhistas na área ambiental, não bastando a determinação judicial para impedir a prática, a continuação ou reiteração da lesão. Tratando-se de conduta empresarial que atinge o direito fundamental ao bem-estar socioambiental dos trabalhadores, é necessário punir o agente infrator, pecuniariamente, para que se repare de forma exemplar o dano emergente da conduta ilícita pretérita, desestimulando novas transgressões ao ordenamento juslaboral, em atendimento ao caráter preventivo-pedagógico da indenização por dano moral coletivo.

O Tribunal Superior do Trabalho, analisou conduta omissiva empresarial na concessão da pausa para recuperação térmica ${ }^{46}$ aos empregados que prestam serviços em ambiente artificialmente frio (câmaras frias ou refrigeradas, com temperatura inferior a $12^{\circ} \mathrm{C}$ ) e na movimentação de mercadorias de ambiente quente para frio e vice-versa, descumprindo norma jurídica que busca tutelar a saúde do trabalhador. No caso, entendeu razoável e proporcional a fixação de indenização por dano moral coletivo no valor de $\mathrm{R} \$ \mathbf{5 0 0 . 0 0 0 , 0 0}$ (quinhentos mil reais), considerando a extensão dos danos causados, a condição econômica do agente infrator e o caráter punitivo-pedagógico da condenação ${ }^{47}$.

\footnotetext{
${ }^{45}$ BRASIL. Tribunal Superior do Trabalho. Recurso de Revista n. ${ }^{\circ}$ 500-97.2012.5.09.0025. Itaú Unibanco S.A. e Ministério Público do Trabalho da $9^{a}$ Região. Relator: Ministro Luiz Philippe Vieira de Mello Filho. 22 mar. $2017 . \quad$ Disponível em: http://aplicacao5.tst.jus.br/consultaunificada2/inteiroTeor.do?action=printInteiroTeor\&format=html\&hig hlight=true\&numeroFormatado=RR $20-\% 20500$ -

97.2012.5.09.0025\&base=acordao\&rowid=AAANGhABIAAANvSAAK\&dataPublicacao=24/03/2017\&localPublic acao=DEJT\&query. Acesso em: 3 abr. 2018.

46 "Art. 253. Para os empregados que trabalham no interior das câmaras frigoríficas e para os que movimentam mercadorias do ambiente quente ou normal para o frio e vice-versa, depois de 1 (uma) hora e 40 (quarenta) minutos de trabalho contínuo, será assegurado um período de 20 (vinte) minutos de repouso, computado esse intervalo como de trabalho efetivo." BRASIL. Decreto-lei n. ${ }^{\circ} 5.452$, de $1^{\circ}$ de maio de 1943. Aprova a Consolidação das Leis do Trabalho. Diário Oficial da República Federativa do Brasil, Rio de Janeiro, 9 ago. 1943. Disponível em: http://www.planalto.gov.br/ccivil_03/decretolei/Del5452.htm. Acesso em: 3 abr. 2018.

47 BRASIL. Tribunal Superior do Trabalho. Agravo de Instrumento em Recurso de Revista (ARR) n. $^{\circ}$ 75100-32.2009.5.18.0191. Marfrig Alimentos S.A. e Ministério Público do Trabalho da $18^{\mathrm{a}}$ Região. Relator: Ministro José Roberto Freire Pimenta. 6 abr. 2016. Disponível em: http: / /aplicaca05.tst.jus.br/consultaunificada2/inteiroTeor.do?action=printInteiroTeor\&format=html\&hig hlight=true\&numeroFormatado=ARR\%20-\%2075100-

32.2009.5.18.0191 \&base=acordao\&rowid=AAANGhAAFAAANnXAAR\&dataPublicacao=15/04/2016\&localPubli cacao=DEJT\&query. Acesso em: 3 abr. 2018.
} 
ISSN 1981-3694

(DOI): $10.5902 / 1981369427743$

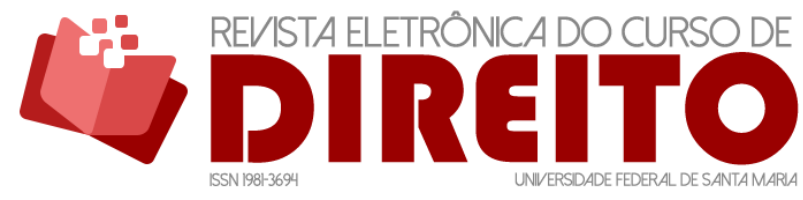

SANÇÕES JURÍDICAS NA ESTRUTURA DE INCENTIVOS DOS AGENTES ECONÔMICOS EM PROL DA TUTELA AMBIENTAL

TRABALHISTA

BenJamin MiRANDA TABAK ANDRÉ VINICIUS MELATTI

Portanto, o pagamento de indenização por dano moral coletivo é a resposta para a conduta do agente econômico que causa lesão a interesses e direitos juridicamente relevantes que transcendem o espaço laborativo e que repercutem negativamente na sociedade. Assim é o caso do direito fundamental ao meio ambiente do trabalho sadio, seguro e equilibrado, cuja degradação ambiental alcança não apenas os atuais empregados, mas todos aqueles que, no futuro, possam vir a laborar no empreendimento econômico. 0 instituto da responsabilidade civil ambiental, nessa situação, visa resguardar a vida, a integridade física e a dignidade da pessoa humana, além do valor social do trabalho e a função social da propriedade.

\section{EFICIÊNCIA DAS MULTAS COMINATÓRIAS FIXADAS EM TERMOS DE AJUSTE DE CONDUTA PELO MINISTÉRIO PÚBLICO DO TRABALHO}

De acordo com o $\$ 6^{\circ}$ do artigo $5^{\circ}$ da Lei n. ${ }^{\circ} 7.347 / 1985$, o Ministério Público pode tomar dos interessados compromisso de ajustamento de sua conduta às exigências legais, mediante cominações, que terá eficácia de título executivo extrajudicial ${ }^{48}$. Trata-se do chamado Termo de Ajuste de Conduta (TAC), considerado um meio alternativo à disposição do Ministério Público do Trabalho na proteção dos direitos metaindividuais trabalhistas, dentre os quais o direito fundamental ao meio ambiente de trabalho equilibrado, saudável e seguro, firmado sob cominações, para o fim de assegurar o cumprimento de suas disposições.

As cominações são compreendidas como sanções civis para a hipótese de descumprimento das obrigações firmadas no Termo de Ajuste de Conduta. Ao lado de serem obrigatórias, as cominações não precisam ter natureza pecuniária, podendo configurar medidas coercitivas de outra natureza, que sirvam, prioritariamente, para garantir a efetividade dos direitos nele concretizados ${ }^{49}$. Todavia, dentre as espécies de cominações, prepondera no

\footnotetext{
48 "Art. 5․ Têm legitimidade para propor a ação principal e a ação cautelar: I - o Ministério Público; [...] $\S 6^{\circ}$. Os órgãos públicos legitimados poderão tomar dos interessados compromisso de ajustamento de sua conduta às exigências legais, mediante cominações, que terá eficácia de título executivo extrajudicial." BRASIL. Lei no 7.347, de 24 de julho de 1985. Disciplina a ação civil pública de responsabilidade por danos causados ao meio-ambiente, ao consumidor, a bens e direitos de valor artístico, estético, histórico, turístico e paisagístico (VETADO) e dá outras providências. Diário Oficial da República Federativa do Brasil, Brasília, 25 jul. 2985. Disponível em: http://www.planalto.gov.br/ccivil_03/leis/l7347orig.htm. Acesso em: 3 abr. 2018.

49 NERY, Ana Luiza de Andrade. Compromisso de Ajustamento de Conduta: Teoria e Análise de Casos Práticos. São Paulo: Revista dos Tribunais, 2010. p.192.
} 
Ministério Público do Trabalho a utilização da multa cominatória para buscar a tutela do meio ambiente laboral, em prol da vida, saúde, integridade física e bem-estar dos trabalhadores.

A fixação de multa cominatória com periodicidade temporal (e.g. diária, semanal, mensal) até o cumprimento da obrigação é a espécie mais comum de cominação no Termo de Ajuste de Conduta $^{50}$, sendo estipulada em valores elevados, com a finalidade de forçar o agressor da ordem jurídica a cumprir a lei ${ }^{51}$. Na condição de coação de caráter econômico, a multa cominatória tem como objetivo primordial influir no ânimo do agente econômico para que cumpra o ordenamento juslaboral. Torna-se necessário, assim, analisar a frequência de estipulação de multas cominatórias pecuniárias nos Termos de Ajuste de Conduta firmados pelo Ministério Público do Trabalho e a sua aptidão para prevenir lesões ao meio ambiente do trabalho, com base nos dados eletrônicos constantes do sistema "MPT Delphos"52.

Procedendo-se à utilização dos filtros "área temática 01 - meio ambiente do trabalho", no campo "lista de investigados e rankings por área temática", verifica-se que o Ministério Público do Trabalho já instaurou 206.967 investigações versando sobre a tutela do meio ambiente laboral, sendo que, até maio de 2017, tramitam com o status “ativo”, ou seja, para apuração da existência de lesão ambiental trabalhista, 30.530 investigações, tendo sido arquivadas 24.317 investigações com a firmatura de Termo de Ajuste de Conduta. A pesquisa também demonstra que há 12.142 investigações em curso para acompanhamento do cumprimento das obrigações firmadas em Termos de Ajuste de Conduta, sob pena de cominações, com somente 558 ações de execuções do TAC na Justiça do Trabalho.

Com base nesses dados, é possível avaliar a eficiência da multa cominatória fixada em Termo de Ajuste de Conduta firmado com o Ministério Público do Trabalho, na ótica da Análise Econômica do Direito, de maneira a verificar a maximização do bem-estar social. Para tanto, se ao assumir o compromisso de cumprir, sob pena de multa cominatória, obrigações de fazer, não fazer e dar, o agente estiver em situação melhor ou igual ao status quo, considera-se que houve eficiência no sentido de Pareto. De outro lado, se na confrontação dos benefícios e custos

\footnotetext{
${ }^{50}$ GAVRONSKI, Alexandre Amaral. Técnicas Extraprocessuais de Tutela Coletiva: a Efetividade da Tutela Coletiva Fora do Processo Judicial. São Paulo: Revista dos Tribunais, 2010. p. 384.

${ }^{51}$ MELO, Raimundo Simão de. Ação Civil Pública na Justiça do Trabalho. São Paulo: LTr, 2014. p. 122.

52 Sistema de Integração Nacional do Ministério Público do Trabalho, criado e desenvolvido pela Comissão de Gestão do MPT Digital e pela Coordenadoria de Análise e Pesquisa de Informações CAPI/MPT.
} 
ISSN 1981-3694

(DOI): $10.5902 / 1981369427743$

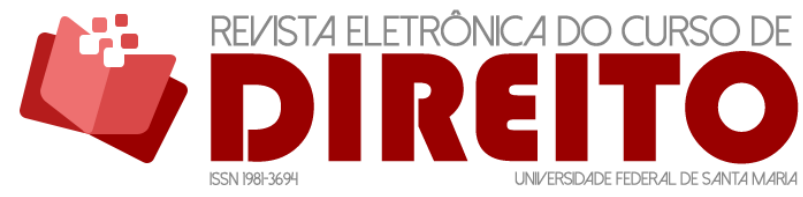

SANÇÕES JURÍDICAS NA ESTRUTURA DE INCENTIVOS DOS AGENTES ECONÔMICOS EM PROL DA TUTELA AMBIENTAL

TRABALHISTA

BenJAMIN MiRANDA TABAK ANDRÉ VINICIUS MELATTI

sociais, a multa cominatória gerou um benefício maior do que o custo total de firmatura do Termo de Ajuste de Conduta, houve eficiência no sentido de Kaldor-Hicks ${ }^{53}$.

Partindo-se da noção de eficiência fundada na maximização do bem-estar da sociedade (Kaldor-Hicks), verifica-se que a estipulação de multa cominatória, em Termo de Ajuste de Conduta firmado com o Ministério Público do Trabalho, tem a aptidão de prevenir condutas comissivas ou omissivas lesivas ao meio ambiente do trabalho, alterando a estrutura de incentivos a que os agentes empresariais estão sujeitos. Isso porque a multa cominatória influencia a decisão de tutela do direito fundamental ao meio ambiente equilibrado, saudável e seguro, evitando a geração de externalidades negativas para os trabalhadores.

Conceituando-se externalidade como o impacto da ação (ou omissão) de um agente sobre um terceiro que não participou dessa conduta, em uma relação econômico-social ${ }^{54}$, bem como o fato de que a questão ambiental pode ser compreendida sob o enfoque da Análise Econômica do Direito ${ }^{55}$, pode-se afirmar que a ausência de garantia do desenvolvimento equilibrado e saudável da vida humana no ambiente de trabalho atinge interesses relevantes da sociedade, gerando malefícios aos trabalhadores. Assim, legitima-se a atuação do Ministério Público do Trabalho, nos termos do artigo 127 da Constituição da República ${ }^{56}$.

A busca do aspecto ótimo do comportamento dos agentes, titulares do direito de propriedade dos bens que compõem o empreendimento econômico, deve ser a perquirição da eficiência ${ }^{57}$, em prol da maximização do bem-estar socioambiental dos trabalhadores. Nesse aspecto, observa-se que o índice de celebração de Termos de Ajuste de Conduta, tendo como objeto a tutela ambiental trabalhista, é relativamente alto no âmbito do Ministério Público do Trabalho, com 36.459 investigações com TACs firmados até maio de 2017, dentre arquivados e

53 TABAK, Benjamin Miranda. Análise Econômica do Direito: Proposições Legislativas e Políticas Públicas. Revista de Informação Legislativa, Brasília, ano 52, n. 205, jan./fev. 2015. p. 324.

${ }^{54}$ PORTO, Antônio José Maristrello; GOMES, Lucas Thevenard. Análise Econômica da Função Social dos Contratos: Críticas e Aprofundamentos. Economic Analysis of Law Review, Brasília, v. 1, n. 2, jul./dez. 2010. p. 204.

55 SAMPAIO, Dayana Almeida Fraga; TABAK, Benjamin Miranda; AGUIAR, Julio Cesar de. A Outorga do Uso da Água à Luz dos Direitos de Propriedade. TABAK, Benjamin Miranda; AGUIAR, Julio Cesar de (Org.). Análise Econômica do Direito: Uma Abordagem Aplicada. Porto Alegre: Núbia Fabris, 2015. p. 97.

56 “Art. 127. O Ministério Público é instituição permanente, essencial à função jurisdicional do Estado, incumbindo-lhe a defesa da ordem jurídica, do regime democrático e dos interesses sociais e individuais indisponíveis." BRASIL. Constituição Federal. Diário Oficial da República Federativa do Brasil, Brasília, 5 out. 1988. Disponível em: http://www.planalto.gov.br/ccivil_03/constituicao/constituicao.htm. Acesso em 2 abr. 2018.

57 PORTO, Antônio José Maristrello; FRANCO, Paulo Fernando. Uma Análise Também Econômica do Direito de Propriedade. Economic Analysis of Law Review, Brasília, v. 7, n. 1, jan./jun. 2016. p. 219. 
ISSN 1981-3694

(DOI): $10.5902 / 1981369427743$

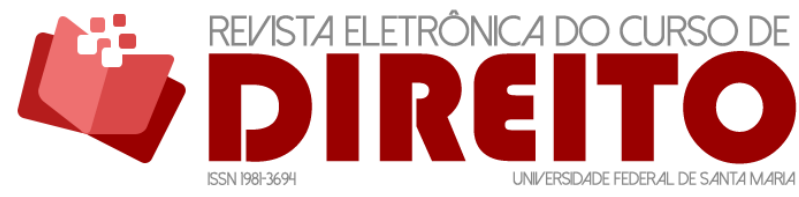

SANÇÕES JURÍDICAS NA ESTRUTURA DE INCENTIVOS DOS AGENTES ECONÔMICOS EM PROL DA TUTELA AMBIENTAL

TRABALHISTA

BENJAMIN MIRANDA TABAK ANDRÉ VINICIUS MELATTI

em acompanhamento, para 30.530 investigações em curso envolvendo o meio ambiente do trabalho e apenas 558 ações de execução na Justiça do Trabalho com essa temática.

Considerando que o postulado da escolha racional prevê que os agentes adaptarão seus comportamentos de forma a reduzir a incidência dos ônus que o direito thes impõe ${ }^{58}$, a multa cominatória pecuniária fixada em Termos de Ajuste de Conduta firmados com o Ministério Público do Trabalho tem alcançado eficácia, no sentido de Kaldor-Hicks, de maneira significativa na tutela do meio ambiente do trabalho, uma vez que a possibilidade de sua aplicação na hipótese de descumprimento das obrigações assumidas acarreta a adoção, no empreendimento econômico, de medidas de prevenção de condições degradantes à vida, saúde e segurança dos trabalhadores, produzindo um aumento do bem-estar socioambiental.

\section{CONCLUSÃO}

À luz do exposto, pode-se concluir que os agentes econômicos, ao organizarem suas atividades, respondem a certos incentivos e, por meio de um comportamento racional, buscam maximizar os ganhos e minimizar as perdas, motivo pelo qual adaptarão seus comportamentos de forma a reduzir a incidência dos ônus que o direito lhes impõe, especialmente com relação à resposta do sistema jurídico para a ação ou omissão que estiver em desconformidade com as suas regras e princípios, nos moldes atuais das funções desenvolvidas pelo instituto da responsabilidade civil ambiental, evitando-se a repercussão negativa da conduta empresarial na vida, saúde e integridade psicofísica dos trabalhadores.

A responsabilidade civil passa a se ocupar na atualidade da potencialidade do dano ambiental, antes mesmo de sua concretização, motivo pelo qual a tutela preventiva dos danos ambientais passa a ter prioridade à sua reparação. Afinal, a ordem econômica é fundada na valorização do trabalho humano e na proteção do meio ambiente, razão pela qual os agentes econômicos devem organizar os seus empreendimentos de maneira a buscar o desenvolvimento equilibrado e saudável da vida humana no ambiente de trabalho, por meio do cumprimento de normas de saúde e segurança do trabalho.

Destacou-se que o princípio do desenvolvimento sustentável, conforme entendimento preconizado pelo Supremo Tribunal Federal, encontra assento constitucional, extraindo-se do seu conteúdo normativo que a incolumidade do meio ambiente não pode ser comprometida por

${ }^{58}$ MACKAAY, Ejan; ROUSSEAU, Stéphane. Análise Econômica do Direito. São Paulo: Atlas, 2015. p. 670. 
ISSN 1981-3694

(DOI): $10.5902 / 1981369427743$

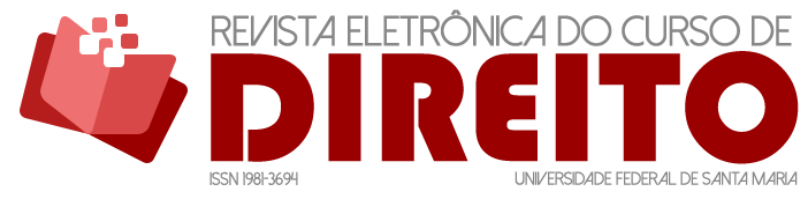

SANÇÕES JURÍDICAS NA ESTRUTURA DE INCENTIVOS DOS AGENTES ECONOMICOS EM PROL DA TUTELA AMBIENTAL

TRABALHISTA

BenJAMIN MiRANDA TABAK ANDRÉ VINICIUS MELATTI

interesses empresariais nem ficar dependente de motivações de índole meramente econômica. Nesse aspecto, afirmou-se que os agentes econômicos, na busca de soluções para a proteção do meio ambiente, devem se pautar sob a perspectiva da sustentabilidade, integrando os aspectos econômico, social e ambiental, tal como definido na Declaração de Joanesburgo sobre Desenvolvimento Sustentável de 2002.

Isso porque o agente econômico preocupado em ser cumpridor de normas jurídicas ambientais deve considerar a internalização de externalidades negativas ocasionadas por sua atividade, em prol do bem-estar socioambiental dos trabalhadores, sob pena de incidência das seguintes consequências do instituto de responsabilidade civil: pagamento de indenizações por danos materiais e morais coletivos. Acrescente-se, ainda, a aplicação de multa cominatória fixada em Termo de Ajuste de Conduta firmado com o Ministério Público do Trabalho. Todas essas sanções jurídicas visam, em último aspecto, garantir o equilíbrio, a segurança e a salubridade do meio ambiente do trabalho, em favor da qualidade da vida humana.

\section{REFERÊNCIAS}

BELTRAMELLI NETO, Silvio; LUSTRE, Paola Stolagli. O Direito Fundamental à Saúde e o Acidente de Trabalho: Por Uma Investigação Mais Precisa do Nexo Causal. Revista do Ministério Público do Trabalho, n. 49. Brasília: LTr, mar. 2015.

BRASIL. Constituição Federal. Diário Oficial da República Federativa do Brasil, Brasília, 5 out. 1988. Disponível em: http://www.planalto.gov.br/ccivil_03/constituicao/constituicao.htm. Acesso em 2 abr. 2018.

BRASIL. Decreto-lei n. ${ }^{\circ}$ 5.452, de $1^{\circ}$ de maio de 1943. Aprova a Consolidação das Leis do Trabalho. Diário Oficial da República Federativa do Brasil, Rio de Janeiro, 9 ago. 1943. Disponível em: http://www.planalto.gov.br/ccivil_03/decreto-lei/Del5452.htm. Acesso em: 3 abr. 2018.

BRASIL. Lei $n^{\circ}$ 6.938, de 31 de agosto de 1981. Dispõe sobre a Política Nacional do Meio Ambiente, seus fins e mecanismos de formulação e aplicação, e dá outras providências. Diário Oficial da República Federativa do Brasil, Brasília, 2 set. 1981. Disponível em: http://www.planalto.gov.br/ccivil_03/leis/L6938.htm. Acesso em: 3 abr. 2018.

BRASIL. Lei $n^{\circ} 7.347$, de 24 de julho de 1985. Disciplina a ação civil pública de responsabilidade por danos causados ao meio-ambiente, ao consumidor, a bens e direitos de valor artístico, estético, histórico, turístico e paisagístico (VETADO) e dá outras providências. Diário Oficial da República Federativa do Brasil, Brasília, 25 jul. 2985. Disponível em: http://www.planalto.gov.br/ccivil_03/leis//7347orig.htm. Acesso em: 3 abr. 2018. 
BRASIL. Lei $\mathrm{n}^{\circ} 10.406$, de 10 de janeiro de 2002. Institui o Código Civil. Diário Oficial da República Federativa do Brasil, Brasília, 11 jan. 2002. Disponível em:

http://www.planalto.gov.br/ccivil_03/leis/2002//10406.htm. Acesso em: 2 abr. 2018.

BRASIL. Superior Tribunal de Justiça. AgRg nos EDcl no REsp 1094873/SP. Agravante: Filipe Salles Oliveira e outro. Agravado: Ministério Público do Estado de São Paulo. Relator: Ministro Humberto Martins. 4 ago. 2009. Disponível em:

https: / / ww2.stj.jus.br/processo/revista/documento $/$ mediado $/$ ?componente=ITA\&sequencial $=89$ 8714\&num_registro=200802154943\&data=20090817\&formato=PDF. Acesso em: 3 abr. 2018.

BRASIL. Superior Tribunal de Justiça. REsp n. ${ }^{\circ} 1115555 / M G$. Ministério Público do Estado de Minas Gerais e Julio Cesar Vieira Pinto. Relator: Ministro Arnaldo Esteves Lima. 15 fev. 2011. Disponível em:

https://ww2.stj.jus.br/processo/revista/documento/mediado/?componente=ITA\&sequencial=10 36983\&num_registro=200900040611\&data=20110223\&formato=PDF. Acesso em: 3 abr. 2018.

BRASIL. Supremo Tribunal Federal. Ação Direta de Inconstitucionalidade (ADIn) n. ${ }^{\circ}$ 3540-1 MC/DF. Procurador-geral da República e Presidente da República. Relator: Ministro Celso de Mello. 1 set. 2005. Disponível em:

http: //redir.stf.jus.br/paginadorpub/paginador.jsp?docTP=AC\&docID=387260. Acesso em: 2 abr. 2018.

BRASIL. Tribunal de Justiça de São Paulo. Apelação n. ${ }^{\circ}$ 0046930-67.2010.8.26.0506. Apelante: Companhia Albertina Mercantil e Industrial e outros. Apelado: Ministério Público do Estado de São Paulo. Relatora: Desembargadora Vera Angrisani. 19 maio 2016. Disponível em: https: / / esaj.tjsp.jus.br/cjsg/getArquivo.do?conversationld=\&cdAcordao=9453741\&cdForo=0\&uui dCaptcha=sajcaptcha_0ef16528492f447f886e4d384f2f57f4\&vlCaptcha=zxD\&novoVICaptcha. Acesso em: 3 abr. 2018.

BRASIL. Tribunal Superior do Trabalho. Agravo de Instrumento em Recurso de Revista (ARR) n. ${ }^{\circ}$ 75100-32.2009.5.18.0191. Marfrig Alimentos S.A. e Ministério Público do Trabalho da $18^{a}$ Região. Relator: Ministro José Roberto Freire Pimenta. 6 abr. 2016. Disponível em:

http: //aplicacao5.tst.jus.br/consultaunificada2/inteiroTeor.do?action=printInteiroTeor\&format= html\&highlight=true\&numeroFormatado=ARR\%20-\%2075100-

32.2009.5.18.0191\&base=acordao\&rowid=AAANGhAAFAAANnXAAR\&dataPublicacao=15/04/2016\&l ocalPublicacao=DEJT\&query. Acesso em: 3 abr. 2018.

BRASIL. Tribunal Superior do Trabalho. Agravo em Recurso de Revista n. ${ }^{\circ}$ 170-

66.2013.5.09.0025. Agravante: Construtora Rva Ltda. Agravado: Ministério Público do Trabalho da $9^{a}$ Região. Relator: Ministro José Roberto Freire Pimenta. 5 abr. 2017. Disponível em:

http: / /aplicacao5.tst.jus.br/consultaunificada2/inteiroTeor.do?action=printInteiroTeor\&format= htmlethighlight=true\&numeroFormatado=ARR\%20-\%20170-

66.2013.5.09.0025\&base=acordao\&rowid=AAANGhABIAAAM7OAAL\&dataPublicacao=11/04/2017\&l ocalPublicacao=DEJT\&query. Acesso em: 3 abr. 2018.

BRASIL. Tribunal Superior do Trabalho. Recurso de Revista n. ${ }^{\circ}$ 500-97.2012.5.09.0025. Itaú Unibanco S.A. e Ministério Público do Trabalho da $9^{a}$ Região. Relator: Ministro Luiz Philippe Vieira de Mello Filho. 22 mar. 2017. Disponível em:

http://aplicacao5.tst.jus.br/consultaunificada2/inteiroTeor.do?action=printInteiroTeor\&format= 
ISSN 1981-3694

(DOI): $10.5902 / 1981369427743$

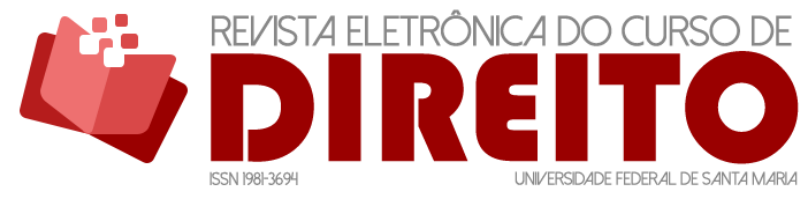

SANÇÕES JURÍDICAS NA ESTRUTURA DE INCENTIVOS DOS AGENTES ECONOMICOS EM PROL DA TUTELA AMBIENTAL

TRABALHISTA

BenJAMIN MiRANDA TABAK ANDRÉ VINICIUS MELATTI

html\&highlight=true\&numeroFormatado=RR $\% 20-\% 20500$ -

97.2012.5.09.0025\&base=acordao\&rowid=AAANGhABIAAANvSAAK\&dataPublicacao=24/03/2017\&l ocalPublicacao=DEJT\&query. Acesso em: 3 abr. 2018.

CÉSAR, João Batista Martins; MELO, Guilherme Aparecido Bassi de. Condenação por Dano à Moral Difusa como Forma de Prevenir e Punir Agressões ao Meio Ambiente do Trabalho. In: JARDIM, Philippe Gomes; LIRA, Ronaldo José de (Coord.). Meio Ambiente do Trabalho Aplicado: Homenagem aos 10 Anos da CODEMAT. São Paulo: LTr, 2013.

COSTA, Marcelo Freire Sampaio. Dano Moral (Extrapatrimonial) Coletivo. São Paulo: LTr, 2009.

DALLEGRAVE NETO, José Affonso. Controvérsias do Dano ao Ambiente de Trabalho. In:

FELICIANO, Guilherme Guimarães; URIAS, João; MARANHÃO, Ney (Coord.). Direito Ambiental do Trabalho: Apontamentos para Uma Teoria Geral. São Paulo: LTr, 2017. v. 3.

DALLEGRAVE NETO, José Affonso. Responsabilidade Civil no Direito do Trabalho. São Paulo: LTr, 2010.

FERRO, Thania Maria Bastos Lima. A Função Punitiva da Responsabilidade Civil em Acidentes do Trabalho. São Paulo: LTr, 2016.

FORNASIER, Mateus de Oliveira. Princípio da Precaução e Regulação do Risco Nanotecnológico: Consequências Econômicas. Economic Analysis of Law Review, Brasília, v. 5, n. 2, jul./dez. 2014.

GAVRONSKI, Alexandre Amaral. Técnicas Extraprocessuais de Tutela Coletiva: a Efetividade da Tutela Coletiva Fora do Processo Judicial. São Paulo: Revista dos Tribunais, 2010.

GEMIGNANI, Tereza Aparecida Asta; GEMIGNANI, Daniel. Meio Ambiente do Trabalho: Precaução e Prevenção: Princípios Norteadores de Um Novo Padrão Normativo. In: Revista do Ministério Público do Trabalho, n. 43. Brasília: LTr, mar. 2012.

LEITE, José Rubens Morato; AYALA, Patryck de Araújo. Dano Ambiental: do Individual ao Coletivo Extrapatrimonial: Teoria e Prática. São Paulo: Revista dos Tribunais, 2015.

MACKAAY, Ejan; ROUSSEAU, Stéphane. Análise Econômica do Direito. São Paulo: Atlas, 2015.

MATTOS, Katty Maria da Costa. Valoração Econômica dos Impactos Causados pela Queima da Cana de Açúcar no Meio Ambiente. 2002. 131 f. Tese (Doutorado em Ciências de Engenharia Ambiental). Escola de Engenharia de São Carlos, São Carlos, 2002.

MEDEIROS NETO, Xisto Tiago de. A Responsabilidade Civil Objetiva: da Teoria da Culpa à Teoria do Risco. Revista do Ministério Público do Trabalho no Rio Grande do Norte, Natal, PRT da $21^{\text {a }}$ Região, set. 2015.

MEDEIROS NETO, Xisto Tiago. Dano Moral Coletivo. São Paulo: LTr, 2012.

MELO, Raimundo Simão de. Ação Civil Pública na Justiça do Trabalho. São Paulo: LTr, 2014. 
NERY, Ana Luiza de Andrade. Compromisso de Ajustamento de Conduta: Teoria e Análise de Casos Práticos. São Paulo: Revista dos Tribunais, 2010.

NÓBREGA, Antonio Carlos Vasconcellos. A Nova Lei de Responsabilização de Pessoas Jurídicas como Estrutura de Incentivos aos Agentes. Economic Analysis of Law Review, Brasília, v. 5, n. 1, jan./jun. 2014.

OLIVEIRA, Liziane Paixão Silva; MONT'ALVERNE, Tarin Cristino Frota. A Evolução da Noção de Desenvolvimento Sustentável na Conferência das Nações Unidas. REI, Fernando; GRANZIERA, Maria Luiza Machado (Org.). Direito Ambiental Internacional: Avanços e Retrocessos. São Paulo: Atlas, 2015.

PORTO, Antônio José Maristrello; FRANCO, Paulo Fernando. Uma Análise Também Econômica do Direito de Propriedade. Economic Analysis of Law Review, Brasília, v. 7, n. 1, jan./jun. 2016.

PORTO, Antônio José Maristrello; GOMES, Lucas Thevenard. Análise Econômica da Função Social dos Contratos: Críticas e Aprofundamentos. Economic Analysis of Law Review, Brasília, v. 1, n. 2, jul./dez. 2010.

SAMPAIO, Dayana Almeida Fraga; TABAK, Benjamin Miranda; AGUIAR, Julio Cesar de. A Outorga do Uso da Água à Luz dos Direitos de Propriedade. TABAK, Benjamin Miranda; AGUIAR, Julio Cesar de (Org.). Análise Econômica do Direito: Uma Abordagem Aplicada. Porto Alegre: Núbia Fabris, 2015.

SAMPAIO, Dayana Almeida Fraga; TABAK, Benjamin Miranda; AGUIAR, Julio Cesar de. A Responsabilidade Civil sob a Ótica da Teoria dos Jogos. In: TABAK, Benjamin Miranda; AGUIAR, Julio Cesar de (Org.). Análise Econômica do Direito: Uma Abordagem Aplicada. Porto Alegre: Núbia Fabris, 2015.

SANTOS, Enoque Ribeiro dos. Responsabilidade Objetiva e Subjetiva do Empregador em Face do Novo Código Civil. São Paulo: LTr, 2008.

SILVA, Ênio Alexandre Gomes Bezerra da; AGUIAR, Julio Cesar de; TABAK. Benjamin Miranda. Incentivos Fiscais Capturados pelos Oligopólios: Uma Perspectiva da Análise Econômica do Direito. In: TABAK, Benjamin Miranda; AGUIAR, Julio Cesar de (Org.). Análise Econômica do Direito: Uma Abordagem Aplicada. Porto Alegre: Núbia Fabris, 2015.

SILVA, Leticia Rebola Volpi. Compensação Moral Coletiva em Decorrência de Ilícitos Ambientais. Revista Bonijuris, Curitiba, v. 27, n. 1, jan. 2015.

TABAK, Benjamin Miranda. Análise Econômica do Direito: Proposições Legislativas e Políticas Públicas. Revista de Informação Legislativa, Brasília, ano 52, n. 205, jan./fev. 2015.

TEPEDINO, Gustavo; BARBOZA, Heloisa Helena; MORAES, Maria Celina Bodin de. Código Civil Interpretado Conforme a Constituição da República. Rio de Janeiro: Renovar, 2006. v. I.

TEPEDINO, Gustavo; BARBOZA, Heloisa Helena; MORAES, Maria Celina Bodin de. Código Civil Interpretado Conforme a Constituição da República. Rio de Janeiro: Renovar, 2006. v. II. 
ISSN 1981-3694

(DOI): $10.5902 / 1981369427743$

UCHÔA, Carlos Frederico Azeredo. A Acepção do Pleno Emprego no Texto Constitucional de 1998. Economic Analysis of Law Review, Brasília, v. 7, n. 2, jul./dez. 2016.

VIANNA, José Ricardo Alvarez. Responsabilidade Civil por Danos ao Meio Ambiente: À Luz do Novo Código Civil. Curitiba: Juruá, 2004.

\section{COMO FAZER A REFERÊNCIA DO ARTIGO (ABNT):}

TABAK, Benjamin Miranda; MELATTI, André Vinícius Sanções jurídicas na estrutura de incentivos dos agentes econômicos em prol da tutela ambiental trabalhista. Revista Eletrônica do Curso de Direito da UFSM, Santa Maria, RS, v. 13, n. 1, p. 49-74, abr. 2018. ISSN 1981-3694. Disponível em: <

https: //periodicos.ufsm.br/revistadireito/article/view/27743 >. Acesso em: dia mês. ano. doi: http://dx.doi.org/10.5902/1981369427743 . 